Louisiana State University

LSU Digital Commons

Faculty Publications

Department of Geography \& Anthropology

1998

\title{
From archive to map to pastoral landscape: A spatial perspective on the livestock ecology of sixteenth-century New Spain
}

Andrew Sluyter

Louisiana State University, asluyter@lsu.edu

Follow this and additional works at: http://digitalcommons.lsu.edu/geoanth_pubs

\section{Recommended Citation}

Sluyter, Andrew, "From archive to map to pastoral landscape: A spatial perspective on the livestock ecology of sixteenth-century New Spain" (1998). Faculty Publications. 54.

http://digitalcommons.lsu.edu/geoanth_pubs/54

This Article is brought to you for free and open access by the Department of Geography \& Anthropology at LSU Digital Commons. It has been accepted for inclusion in Faculty Publications by an authorized administrator of LSU Digital Commons. For more information, please contact gcoste1@lsu.edu. 


\title{
From Archive to Map to Pastoral Landscape
}

\author{
A Spatial Perspective on the Livestock Ecology \\ of Sixteenth-Century New Spain
}

\section{Andrew Sluyter}

While the documents last we can hunt up the story of every strip of occupied land. I can give you that historical bird's eye view.

The European invasion of the Americas rejoined two ecosystems that had been diverging since the Pangean supercontinent fragmented some 200 million years ago. On a hemispheric scale, exotic pathogens exploded through native populations, Old World biologies and institutions filled empty niches to bursting, and capitalists commodified landscapes, accumulating space and extinguishing species. On a regional scale, much still remains unclear, especially the initial ecological effects and processes of what Alfred W. Crosby labeled the "Columbian Exchange."

Because Spain established the first substantial European presence in the New World using livestock integral to frontier expansion, the ecological effects of cattle and sheep in sixteenth-century New Spain remain as central to environmental history as a comprehensive evaluation of those effects remains elusive and controversial. For New Spain, now central Mexico, some scholars have claimed a leading role for livestock in the ecological upheaval; others have just as persistently denied it. In the former view, a metaphorical plague of sheep and cows pervasively degraded the environment. An exponential increase in livestock densities resulted in extreme overgrazing, a decrease in vegetation cover, more frequent and greater floods, and dramatic soil erosion. In the latter view, the introduction of livestock coincided with environmental recovery. By the time the Spaniards arrived in 1519, high population densities were already testing environmental thresholds, with native agriculture periodically disrupting vegetation cover and causing the erosion of soil from hillside fields. As native populations declined in a series of sixteenth-century 
epidemics, vegetation invaded abandoned fields and restabilized slopes. Only then did the Spanish flocks and herds expand; through the use of conservationist management practices such as transhumance, overgrazing rarely occurred. Livestock, from that perspective, remains innocent of any immediate, widespread degradational effect on the environment beyond influencing vegetation composition (that is, the particular species involved as opposed to the vegetation type, be it woodland or grassland). Later environmental depredations of the nineteenth and twentieth centuries have resulted from increasing integration into the global economy rather than from the sixteenth-century diffusion of traditional Iberian pastoralism. ${ }^{2}$

On both sides of this controversy, the most convincing conclusions derive from quantitative data rather than from the anecdotal comments of sixteenth-century observers, environmental degradation being a slippery and equivocal concept. The voluminous, systematic records of the colonial administration invite such quantitative analysis: calculation of changes in livestock density in space and time for correlation with archival and field evidence of environmental stability or degradation. The primary database consists of the volumes in the Mercedes and Tierras sections of the Archivo General de la Nación in Mexico City. The Kraus Collection at the Library of Congress and the Ayer Collection of the Newberry Library each contain an additional volume of mercedes, the viceregal land grants awarded to cattle and sheep ranchers. Those volumes primarily contain grants for farmland and estancias, the livestock ranches, but also hold papers for building lots and other land uses. The grants specify the date of the award, the awardee, the location, the number of land units, and whether the land units were for ganado mayor or ganado menor. As progressively specified in a series of viceregal ordinances beginning in 1536 , ganado mayor grants implied cattle, unless specified for other large livestock such as horses or mules; they encompassed a legal area of 1,747 hectares, and beginning in the early 1560 s, a minimum stocking rate of 500 head. Ganado menor grants implied sheep, unless specified for other small livestock such as goats or pigs; they encompassed a legal area of 776 hectares and a minimum stocking rate of 2,000 head. ${ }^{3}$

This database, although enticing, does not readily yield a quantitative analysis of livestock densities without first confronting three confounding methodological issues: determination of the number of estancias granted in any particular region, determination of the areas of those estancias in hectares, and determination of the number of livestock grazing those estancias, and consequently the regional livestock density in number of head per hectare. The extant estancia grants might represent only a fraction of the total number that the scribes originally recorded in the viceregal register. The volumes of mercedes roughly span the first century of colonization and contain some ten thousand land grants. While informal granting by local officials began during the 1520 s and formal granting by the first viceroy followed in the 1530s, viceregal scribes did not begin registering the grants until 1542, more than two decades after the introduction of livestock; within a century, land granting had virtually ceased. Six further lacunae, totaling thirteen years, occur after 1542 . 
In addition to missing years, several other factors complicate any analysis of the mercedes records. First, the simultaneous use of several register volumes might not necessarily indicate complete preservation. Within the Marquesado del Valle, Hernando Cortés and his heirs, rather than the viceroys, made grants (actually perpetual leases) which do not appear in the mercedes records. Second, the actual areas of the estancia grants might not have encompassed the stipulated 1,747 hectares for cattle and 776 hectares for sheep. Viceregal ordinances clearly specify squares with a north-south orientation, one league on a side for cattle and onethird of a league on a side for sheep. Yet, because those same ordinances stipulate that estancias must be one league apart for cattle and one-half league apart for sheep, Lesley Byrd Simpson infers that "each estancia was surrounded by a belt of open land at least double the size of the piece granted." While that stipulation might refer to the distance between the headquarters of each estancia (ideally located at the center of each grant), making no provision for a buffer space between neighboring ranches, the rudimentary state of surveying meant that the actual estancias could have only approximated legal guidelines. Third, the actual stocking rates might have exceeded the levels stipulated in the mercedes from the 1560 onward. Those rates established a minimum number to "prove up" a grant, to borrow the jargon of another frontier, rather than a prescribed maximum. Even more troublesome, high livestock densities do not necessarily equate with overstocking, which implies exceeding the sustainable stocking rate to the point of overgrazing and destruction of the range. Since different environments and management practices have a wide range of sustainable stocking rates, or "carrying capacities," and since the Spaniards had long experience in the use of transhumance to mitigate the effects of high livestock densities in similar Iberian environments, any analysis of livestock densities should include both environmental and cultural contexts. ${ }^{4}$

Although he did confront them, Simpson failed to resolve these three issues in his seminal quantitative analysis of livestock densities and environmental change in New Spain, an ecological complement to François Chevalier's contemporaneous socioeconomic study. Subsequent works have not resolved these methodological problems or the controversy over the environmental effects of livestock. As a recent and prominent example of that controversy, Elinor Melville posits that a "plague of sheep" descended on the sixteenth-century Valle del Mezquital and wreaked environmental havoc. In contrast, Karl and Elisabeth Butzer argue for much lower livestock densities and a lack of environmental degradation until much later in the colonial period, even while relying on the same database of land grants as Melville. A test of a cartographic method applied to similar data from the tropical lowlands fronting the Gulf of Mexico suggests a partial resolution to all three methodological issues and contributes to a better understanding of the effects of livestock on a particularly relevant environment. While mapping of the land grants tentatively resolves the first two issues, this study focuses on how such mapping also facilitates comparison between sixteenth-century livestock densities and those derived from the first Mexican livestock census, taken in 1902. The resulting spatial perspective permits an evaluation of livestock densities relative to range carry- 
ing capacity and management practice, effectively placing the livestock invasion in its environmental and cultural contexts. ${ }^{5}$

\section{Archive, Map, and Landscape}

The Gulf Coast lowlands near the port of Veracruz bore the initial brunt of the Spanish invasion, the epidemics, and the livestock; few environments have more relevance for understanding the archetypal ecological consequences of the introduction of livestock into New Spain and the Neotropics. The region encompasses the coastal plain and piedmont, stretching from the Gulf to the 500-meter contour, an elevation the inhabitants associate with the transition to the more temperate escarpment of the Sierra Madre Oriental. To the north and south, transitions to humid climates bound these subhumid lowlands. Gregorio de Villalobos introduced cattle, the first in New Spain, and a transhumant herding ecology around 1521. By the end of the sixteenth century, the Veracruz district had become the quintessential pastoral landscape of New Spain: vast herds of cattle grazed the coastal plain, while transhumant flocks of sheep from the highlands wintered in the dunes and on the piedmont. Despite the district's prominence in the livestock economy and relevance to environmental history, the research record pertaining to the colonial upheaval in these lowlands remains inexplicably brief. ${ }^{6}$

Mapping land grants facilitates a quantitative, spatial perspective on that dramatic landscape transformation and an evaluation of the relationship between livestock densities and environmental effects (Figure 1). Seven partial listings of land grants allowed the recovery of documentation for 228 estancias, with four additional estancias recovered from information contained in documentation for neighboring grants. Mapping the locations of those grants entails several preliminary operations: paleographic transcription, orthographic and terminological interpretation, and paleotoponym reconstruction. Most essentially, localizing individual grants with acceptable precision requires spatially reconciling the overall granting pattern. The precision of localization varies from grant to grant. At one extreme, locational details - including boundaries, extant toponyms, and associated maps - facilitate a precision of \pm 2 kilometers. At the other extreme, generic descriptions, lack of extant toponym and landscape referents, and lack of maps lowers precision to \pm 10 kilometers. Overall, the more precise localizations establish a series of interconnected grids that more closely define the locations of problematic grants. The end result is a fair conceptual representation of the spacetime patterning of land granting, and not (by any methodological sleight of hand) a cadastral map. ${ }^{7}$

The series of synoptic maps demonstrates that the lacunae in the mercedes register represent the actual rhythm of the granting process, a function of changing political and economic context rather than an artifact of missing documents (Figure 2). By 1619, with the end of granting in the study region, only the Cotaxtla and Rinconada enclaves of the Marquesado del Valle and the central piedmont remain as significant blanks on the map. The first blank reflects occupation of the 
Figure 1. Land Grants for Estancias in the Veracruz Lowlands.

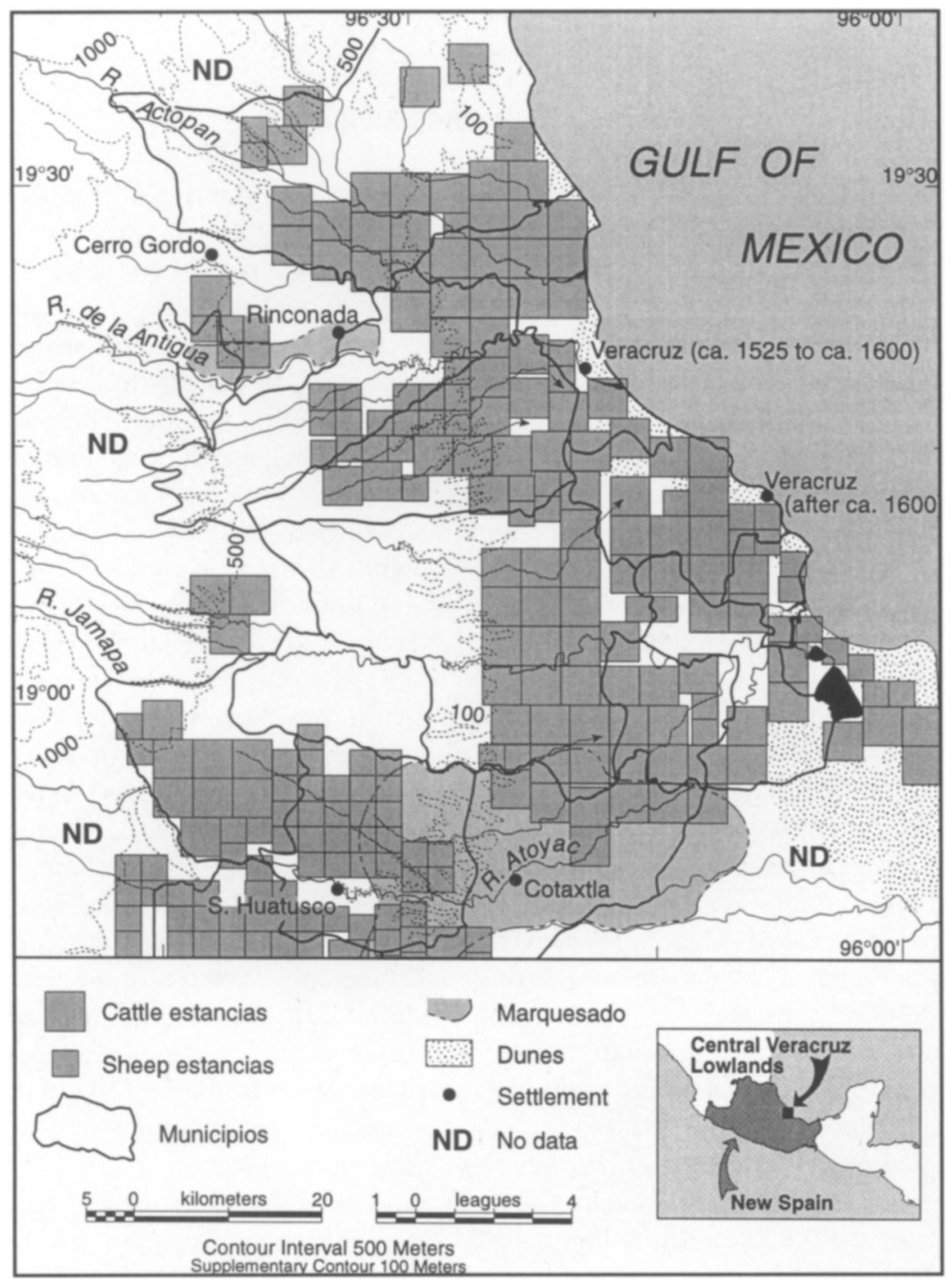

landscape by leases rather than grants; those grants which do intrude on the Marquesado date to periods of sequestration and viceregal control. The second blank reflects the inaccessibility of the central piedmont, the difficulty of northsouth movement across the deep ravines, and the consequent isolation from the caminos reales, the royal highways, to the north and south. Since only four out of the 232 estancias mapped lack extant grants, preserved either in AGN-Mercedes or other repositories, the space-time patterning evident in the synoptic maps con- 
Figure 2. Expansion of the Pastoral Landscape by Decade.

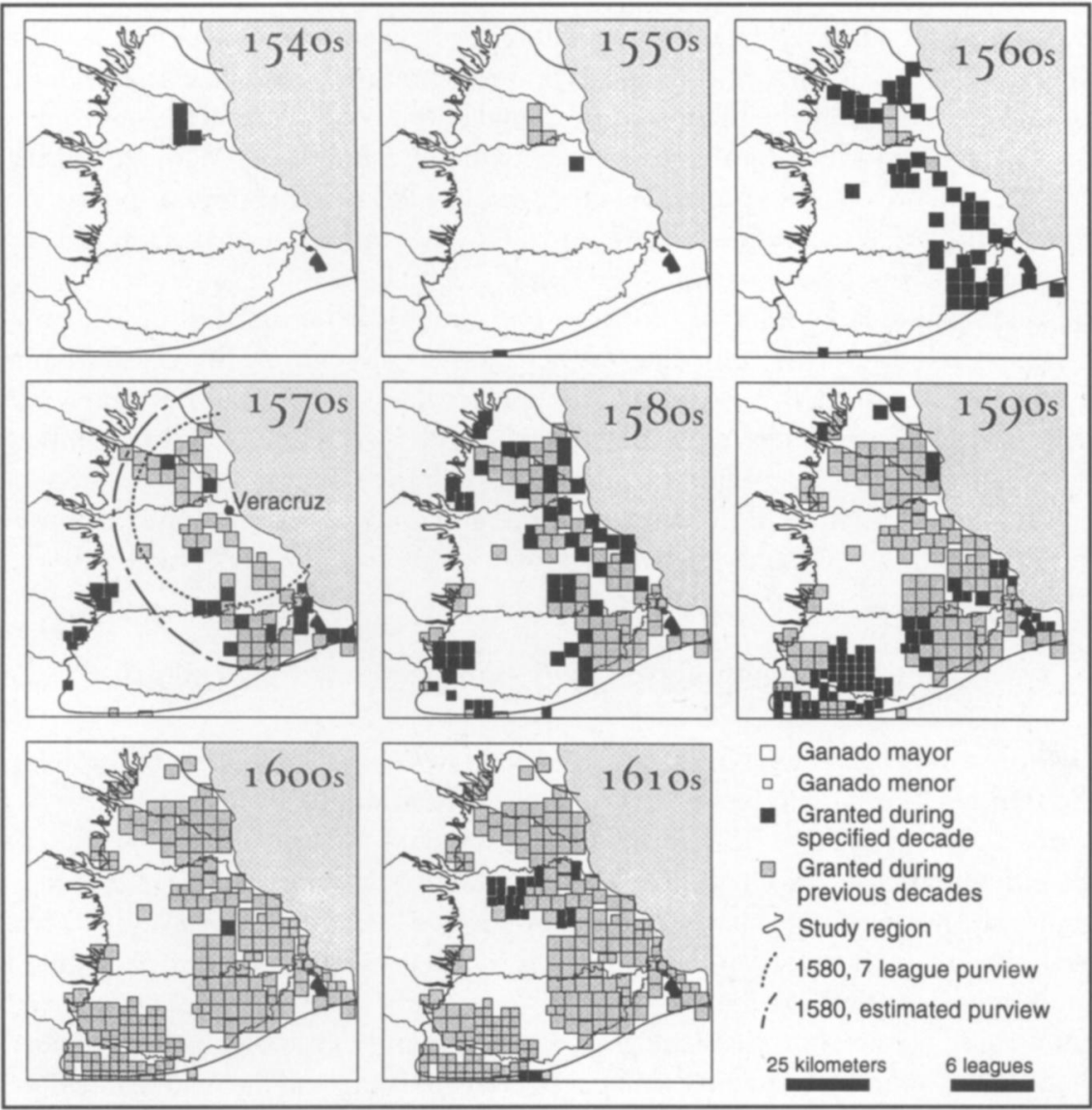

firms that no significant spatial lacunae match the putative temporal lacunae in the archival record and that Spanish space accumulation proceeded through viceregal granting rather than through purchase from natives or through "squatting." The granting process eventually absorbed all of the precocious estancias of the 1520 s and 1530 , with the ranchers seeking the security of legal title as the pastoral landscape filled; in turn, the mercedes themselves more fully and consistently specified the stipulations of the ordinances (increasingly so with the land rush of the 1560 s). Consequently, interpolating between years of heavy granting to adjust for mercedes presumed to have been lost, or inferring squatters' estancias to adjust for land occupied but never granted, Melville's addition of more than 100 percent to the documented estancias seems unwarranted, at least for the central Veracruz lowlands. ${ }^{8}$

The series of synoptic maps also demonstrates that the legal areas of 1,747 hectares for cattle estancias and 776 hectares for sheep estancias represent a close 
approximation of their actual manifestations on the landscape. The blanks among the densest groups of estancias in 1619 could represent a few missing mercedes, but more likely they reflect the slight difference between the conceptual and the operational, the neighboring estancias and a scattering of caballerías, the farmland grants, co-opting the interstices. Minimal buffer zones around the new Spanish and surviving native communities account for other interstices. While the actual grants could only have approximated the stipulated shapes and dimensions, in no case could any estancia have been "surrounded by a belt of open land at least double the size of the piece granted," thus justifying the multiplication of the existing legal area by a factor of three. The central piedmont did serve as wetseason range, the cattle retreating to their home estancias on the coastal plain during the dry season. In ecological terms, that local transhumance does not equate with Simpson's hypothesized buffer zone around each estancia. Rather, understanding the environmental implications of that range management practice requires a spatial analysis of livestock densities and an evaluation of whether those densities entailed overstocking and its corollary, environmental degradation. ${ }^{9}$

\section{Counting Sheep, Cattle, and Standard Livestock Units}

Determinations of regional livestock densities have basically relied on multiplying the number of estancias by the legally stipulated, minimum stocking rates -500 head of cattle and 2,000 head of sheep per estancia - and dividing by the area of the entire region. In the environs of Veracruz, the 117 cattle and 115 sheep estancias granted by 1619 amounted to 58,500 head on 204,399 hectares for cattle and 230,000 head on 89,240 hectares for sheep. Assuming that livestock grazed on granted lands only, densities would have been 0.29 head per hectare for cattle and 2.6 head per hectare for sheep. If livestock grazed throughout the 525,000-hectare region, densities would have been 0.16 head per hectare for cattle and 1.4 head per hectare for sheep, each species grazing nongranted lands in proportion to granted lands: 365,477 hectares for cattle and 159,553 hectares for sheep. ${ }^{10}$

The many references to stocking rates that exceed the legal minimum, sometimes by an order of magnitude, suggest a major flaw in that procedure and have prompted a methodological alternative. Melville-scouring documents related to wills, court cases, censuses, and especially native complaints against Spanish ranchers-notes scattered references to livestock numbers, extrapolates those numbers to the entire Valle del Mezquital, and calculates livestock densities for ten subregions. The Veracruz region, in contrast, because of rapid and extreme native depopulation typical of the lowlands, lacks such records of native litigation against ranchers. Instead, a single observation made by the district's alcalde mayor, the ranking crown official, in a geographical report of 1580 provides a gross estimate: 150,000 cows and mares, undoubtedly brood mares to provide mules for the port traffic, grazed within little more than seven leagues of Veracruz, and "innumerable sheep" descended from the highlands to overwinter. Since no precise jurisdictional boundaries existed, and since this particular alcalde mayor displayed a 
tendency to progressively shorten leagues with increasing distance from his desk, as evident from locational references to several settlements, the exact area of his purview remains uncertain. An analysis of the offices of grant inspectors provides a rough delineation, revealing that the jurisdiction included the entire region exclusive of the southwest quadrant (those grants being inspected out of Santiago Huatusco). By the end of the 1570 s, the alcalde mayor's purview included 57 cattle estancias and 8 sheep estancias. On the basis of the minimum stocking rates, those grants represented 28,500 cattle and horses and 16,000 sheep. Even allowing for additional head grazing on leases in the two enclaves of the Marquesado, for a few missing mercedes, and for some exaggeration on the part of the alcalde mayor, 28,500 remains far below 150,000, and 16,000 is hardly "innumerable." For large stock alone, the geographical report raises the possibility of densities five times the legal minimum."

That alternative method possibly overestimates livestock densities by relying on the nonsystematic data of lawsuits and geographical reports. For example, most of Melville's livestock numbers derive from complaints of crop damage lodged against Spanish ranchers by native communities, suggesting possible exaggeration of livestock numbers to support such charges. Similarly, the alcalde mayor of Veracruz, lacking an accurate livestock census, might well have favored a liberal estimate, thereby lauding the productivity of his jurisdiction. But together the two methods do provide a range of probable estimates: for cattle, a density of between 0.29 head per hectare, the legal minimum, and 1.43 head per hectare, five times that minimum; for sheep, although much more tentative given the vague "innumerable" of the geographical report, between 2.6 and 12.9 head per hectare.

Given the paucity of data, a range of gross estimates remains the most credible method for reconstructing probable livestock densities, but determining which end of such a range might be the most probable, and thus evaluating the environmental interactions, requires comparison with an analogous context with better data. In an early effort at such a comparison, Simpson contrasted the de jure minimum density of 0.29 head of cattle per hectare against twentieth-century range management practice in the United States and concluded that it "seems altogether improbable that any grazing land could support" such densities "for any length of time." This comparison between tropical and temperate environments was perhaps the best possible at the time, but a better environmental analog would be tropical and subtropical Africa, where cattle densities range between o.6 and 2.4 head per hectare. Yet even that comparison biologizes pastoralism, ignoring spatial and temporal variability in cultural contexts. Even a comparison with the current livestock density of the Veracruz region itself -0.5 to 2.0 "animals" per hectare-would ignore the great technological, social, political, and economic changes since the colonial period. ${ }^{12}$

The first Mexican livestock census provides relatively accurate, high resolution data for the environs of Veracruz in the early twentieth century, an environmental and cultural context quite similar to the colonial study region and therefore the most appropriate analog. At the time of the 1902 census, during the last decade of the Porfiriato, the study region's livestock economy prospered by focusing on beef 
production for urban markets. Sheep production had declined with the liberalization of international trade and competition from imported textiles. Otherwise, the pastoral ecology remained similar to that of the colonial period, albeit with several major adjustments - the improvement of transportation infrastructure, the nineteenth-century introduction of more productive and palatable African grasses, and the initial replacement of criollo stock with specialized breeds. The rural population was beginning to rise from its colonial nadir, but it remained relatively low until after the impending revolution, subsequent agrarian reform, and agricultural intensification on the basis of irrigation projects. In this context, the livestock densities of 1902 should represent the apogee of the colonial-type pastoral ecology and provide a reasonable analog to evaluate the range of estimates of colonial livestock densities and their potential for environmental degradation..$^{13}$

The census provides counts by municipio for cattle, horses, mules, sheep, goats, donkeys, and pigs. Comparing those data with the estimates for the colonial period requires normalization to standard livestock units (SLU) and mapping. The following analysis categorizes cattle, horses, and mules as large livestock, sheep and goats as small livestock, and disregards donkeys and pigs as domestic livestock outside of the dominant pastroecosystem. The analysis also subsumes immature livestock - calves, lambs, colts, and kids - under the mother-juvenile pair since both the stipulations of the mercedes and the 1902 census concern the livestock capital rather than the annual product. The conversion of all livestock to SLU normalizes head of small livestock to head of large livestock, factoring out the changing proportions of sheep and cattle over space and time, as well as any possible bias arising from grants for cattle estancias actually supporting horses or sheep and vice versa. As a gross generalization, a standard ewe unit of 50 kilograms would consume 1.69 kilograms of dry matter per day, and a standard cow unit of 350 kilograms would consume 7.28 kilograms per day. Those live weights approximate those of the criollo cattle and Merino and criollo sheep of sixteenth-century New Spain. The consumption ratio of large to small livestock-1 to 4.3 -suggests a similar stocking ratio and a factor of 0.23 for normalizing number of sheep to number of cattle. In contrast, the mercedes specify 0.29 head per hectare for cattle and 2.6 for sheep, a ratio of 1 to 9 , roughly twice the ratio derived from consumption analysis. Seemingly, the stipulated minimum stocking rates took the transhumance of Spanish pastoralism into account. As opposed to parochial cattle, the peripatetic sheep grazed a given estancia for only half of the year (moving between summer and winter ranches) and thus could maintain approximately twice the stocking rate that the consumption analysis suggests. Given that transhumance, the ratio of sheep to cattle densities that the mercedes themselves specify yields the most appropriate normalization factor: 1.o large livestock to 1.0 SLU, and 9.0 small livestock to 1.o SLU. That normalization factor has the credibility of being rooted in the primary data of the mercedes themselves and of being deducible from biological and cultural processes: ungulate consumption and Spanish transhumance. Employing SLU not only factors out the changing proportions of sheep, cattle, and other livestock over space and time, but factors out the confounding effect of transhumance, a central trait of Spanish pastoralism. ${ }^{14}$ 


\section{Comparing Counts: 1902 and 1619}

The 1902 data aggregate at the municipal level, dictating the maximum scale of analysis. In comparison to the 5,250-square-kilometer study region, the included municipalities have a combined area of 4,814 square kilometers. Several of the municipalities extend minimally beyond the study region; several other municipalities only slightly impinge on its margins and do not warrant inclusion. Because the entire area of each municipality does not comprise pasture, and because the calculations assume grazing throughout the entire area rather than on the granted estancias alone, the statistics inescapably underestimate the livestock densities for pasture lands. That bias probably yields a somewhat low density for such mountainous municipalities as Actopan relative to such floodplain municipalities as Jamapa, but the primary goal remains an evaluation of the 1619 densities through comparison with the analogous pastroecosystem of 1902, not an explanation of differences among municipalities except as that issue relates to the primary goal. The assumption that livestock grazed throughout the entire area rather than on the granted estancias alone follows from the Spanish practice of grazing ungranted lands and crop stubble as commonage. ${ }^{15}$

Table 1 and Figure 3 summarize the 1619 and 1902 livestock densities in SLU per hectare. The included grants comprise some 89 percent of the 232 grants in the study region. Generally, much higher livestock densities appear in 1619 than in 1902. The minimum regional estimate for 1619 , defined by the de jure minimum stocking rates, is more than twice the 1902 regional density. The maximum regional estimate for 1619 , defined as five times the de jure minimum stocking rates (on the basis of the alcalde mayor's observation), is more than eleven times the 1902 regional density. Only Adalberto Tejeda has a higher density in 1902 than the high 1619 estimate. The 1902 densities for Medellín and Boca del Río fall within their 1619 ranges. ${ }^{16}$

The comparison suggests that even the low estimate for 1619 is high relative to the 1902 carrying capacity, and by analogy, equally high relative to the 1619 carrying capacity. The high estimate for 1619 implies environmental disaster. Conversely, the relative differences in livestock densities between 1619 and 1902 might be misleading, with the much lower regional SLU population of 1902 grazing on a proportionately smaller area of pasture than was available in 1619 . Postulating more comparable 1619 and 1902 livestock densities would necessarily assume a vast reduction in pasture area, the 34,204 SLU of 1902 grazing on only 45 percent of the pasture lands of 1619. That seems unlikely given that in 1902 the livestock economy was booming while the pastoral ecology remained similar to that of the colonial period, except for better transport infrastructure and the introduction of African grasses. If anything, the area and productivity of pasture lands, and thus the regional carrying capacity, should have been higher in 1902 than in 1619. Supporting that logic, Adalberto Tejeda counters the general pattern of lower densities in 1902 than in 1619 only because during the sixteenth century the central piedmont remained isolated from the main transport axes. Boca del Río presents a special case, possibly because of break-of-bulk feedlot operations near the port of Veracruz in 1902 . 


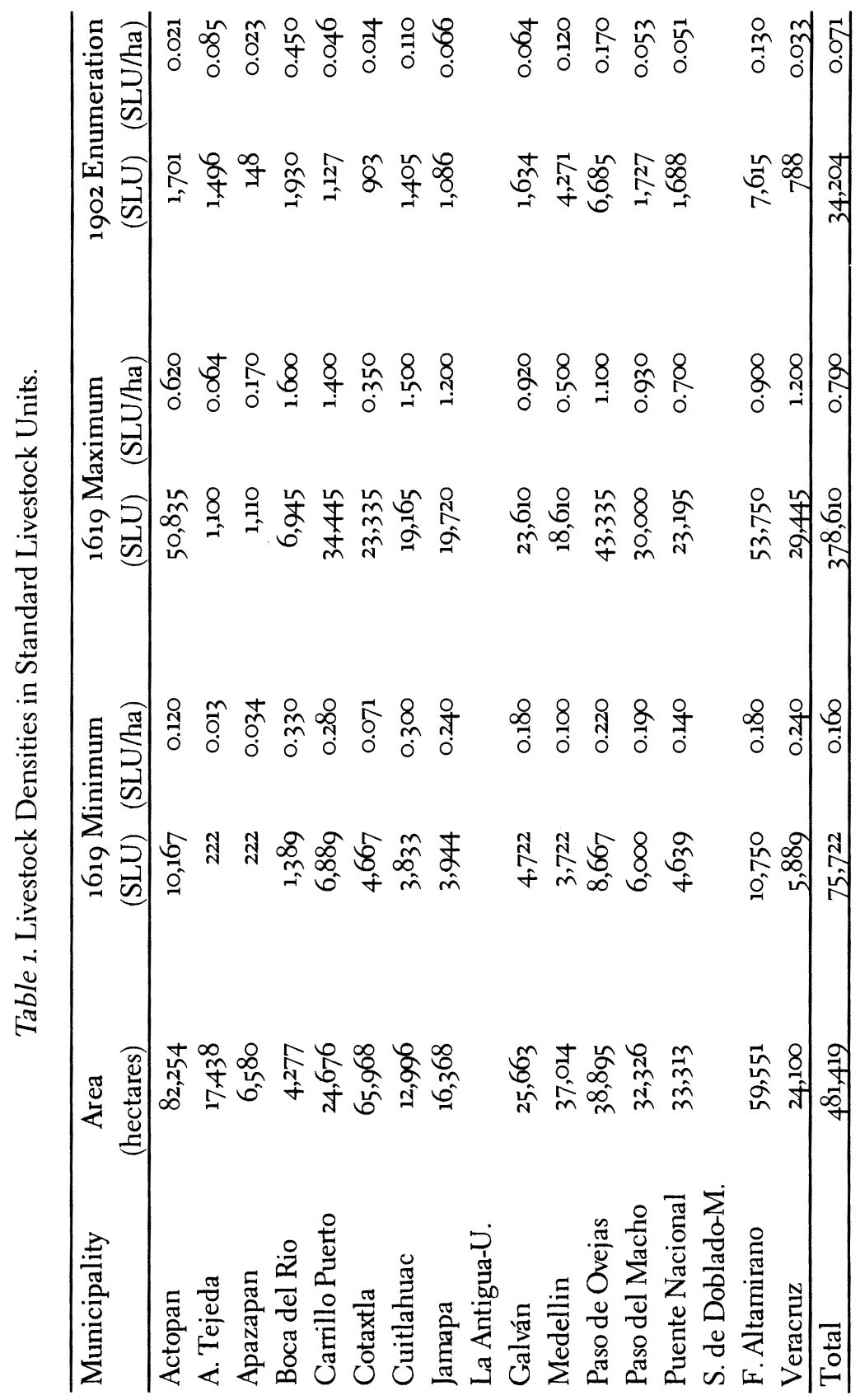




\section{The Pastoral Environment}

Mapping the land grants helps to resolve two of the most persistent methodological issues regarding the use of the mercedes record to reconstruct environmental history. That method, at least for the lowlands of central Veracruz, demonstrates that the extant grants provide a nearly complete record of the spatial and temporal dimensions of Spanish pastoralism. While the distinct environmental and cultural contexts of other regions - particularly of such highland sheep regions as the Valle del Mezquital, where native depopulation was not as sweeping - arguably might have resulted in different processes of space accumulation than those of the cattledominated lowlands, only further research can demonstrate those differences. Cartographic methods would lend rigor and credibility to such research.

Mapping of the estancias does not so clearly address the third methodological issue: evaluation of livestock densities. But the cartographic method does allow comparison of a range of probable densities - from low values based on the stipulations of the mercedes to high values based on sporadic observations - with the closest environmental and cultural analog for which relatively precise data are available. On the basis of comparison with the 1902 census, even if the de facto 1619 density did not exceed the de jure minimum, the first century of colonization ended with livestock occupying most of the best pasture lands in extremely high densities relative to the range's carrying capacity. The high 1619 estimate, based on the alcalde mayor's geographical report, seems improbable. Other estimates based on fragmentary data, such as those for the Valle del Mezquital that Melville bases on lawsuits, also raise suspicion. ${ }^{17}$

Even accepting the low estimate for the Veracruz lowlands, the still lower 1902 density suggests that cattle and sheep were pushing at the range's ecological limit by the end of the sixteenth century; physical evidence of environmental degradation should be preserved in the sediments of the lakes and lagoons of the coastal plain. Overgrazing should have resulted in devegetation, soil compaction, increased runoff, and soil erosion. But analysis of the sediments of Laguna Catarina, a small lake located on the coastal plain near the Río de la Antigua, reveals no environmental impact during the colonial period other than a sharp rise in the influx of carbon and phosphorous. The lowland vegetation types seem to have remained stable, and no major soil erosion events or changes in the runoff regime of streams occurred in Laguna Catarina's watershed. Burning of pasture and tons of ruminant feces resulted in dramatic influxes of carbon and phosphorous and no doubt were, in conjunction with introduced plants, altering the study region's vegetation composition, but vegetation type and biomass probably did not much change during the colonial period. ${ }^{18}$

The only evidence for land-cover change severe enough to cause slope destabilization comes from the Prehispanic period. The upward trend in the proportion of phosphorous in Laguna Catarina's sediments from approximately 1250 to 500 $\mathrm{BC}$ indicates slash-and-burn forest clearance for shifting cultivation and increasing population during the Preclassic and Classic periods. A pulse of carbon and phosphorous around $\mathrm{AD} 500$ correlates with a dramatic influx of freshly eroded sand. 
Figure 3. Livestock Densities, 1619 Minimum and 1902 Census.

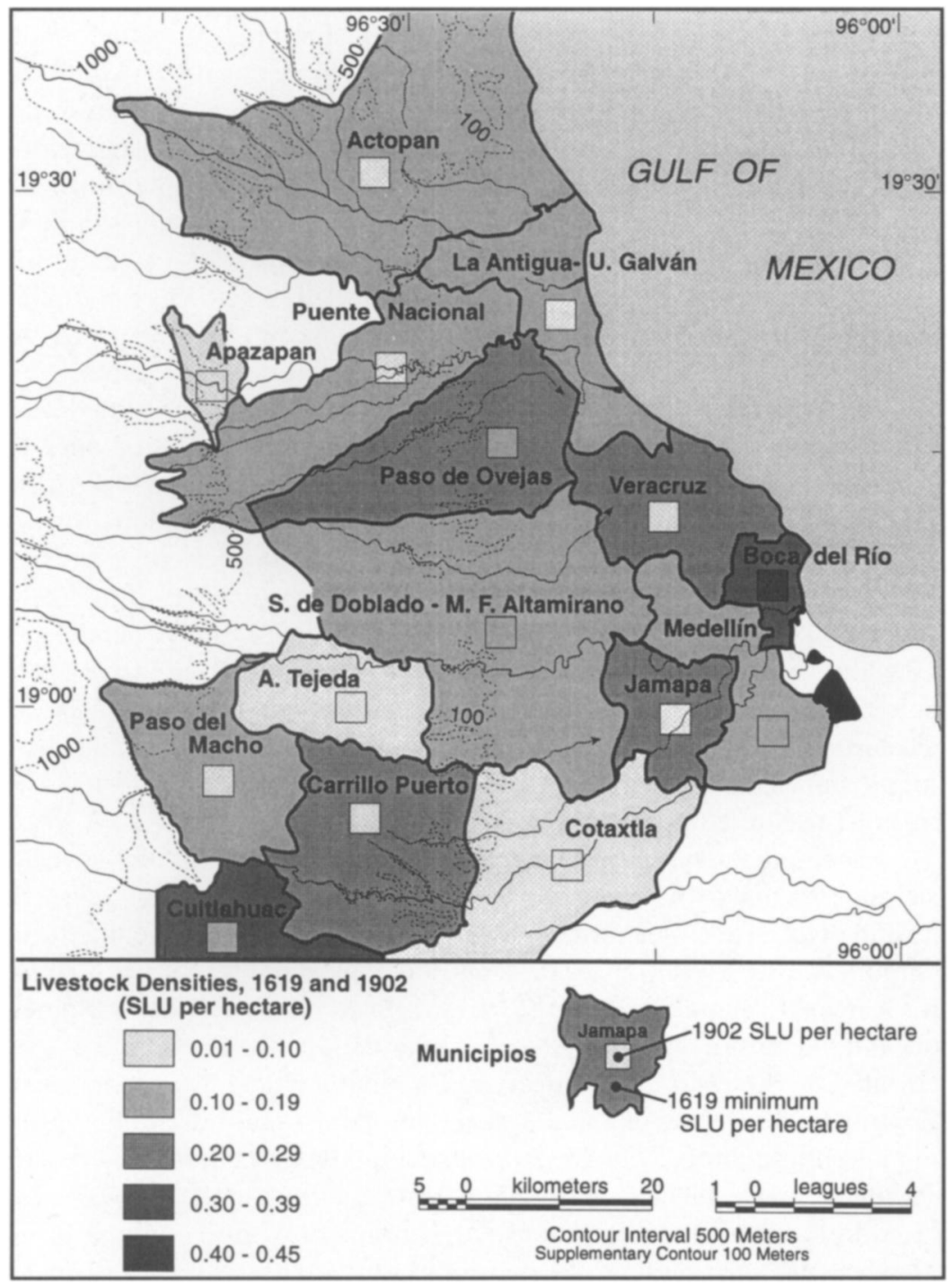

Just as in the Maya lowlands and the central highlands, apparently, Prehispanic intensification of land use eventually resulted in slope destabilization. In this context, colonial ranching was environmentally benign, although directly juxtaposing a few centuries of Spanish land use with millennia of native land use would not yield a valid comparison. ${ }^{19}$

Intensification of the livestock ecology to alleviate grazing pressure would be an unlikely explanation for the incongruous correlation between environmental sta- 
bility and seemingly extreme livestock densities during the sixteenth century. The mercedes record does not substantiate the possibility of such intensification, or in other words, of the cultivation of fodder as opposed to foraging. By 1619 , the viceroys had granted only ninety-two caballerías of farmland in the region. Even if exclusively dedicated to fodder production, ignoring the minimal additional feed available as stubble in fallow fields, those farms could have fed a mere 600 SLU. ${ }^{20}$

Alternatively, but equally as unlikely, the much lower 1902 rates may reflect a reduction in carrying capacity as a result of overgrazing and deterioration of pasture during the intervening four centuries. All of the other data prior to 1902 remain as fragmentary and equivocal as those of the sixteenth century, but the vast herds seem to have persisted until late in the nineteenth century. Livestock densities were as high or higher through the eighteenth century as in 1619: "From Veracruz and other places along the coast, roads go to Mexico [City] through Orizaba, Jalapa, and Ixhuatlán de los Reyes. . . . In the haciendas and ranches of that aforesaid region during the years 1765 and 1766 there were more than 200,000 head of cattle, more than half of them feral." In the middle of the nineteenth century, a local land owner reported that "thousands of cows pasture in the rich juicy grass," and that neither "towns nor villages are found in these extensive districts, but merely here and there the solitary farms of the cattle-proprietors, or of the herdsmen." A foreign traveler also observed the persistent fertility of the landscape and suggested the livestock population's order of magnitude on the basis of the herds of the largest landowner of the nineteenth century: "Much of this land is of good quality, and would produce cotton and sugar most profitably. Very little of it is in cultivation, with the trifling exception of the chili and corn patches. General Santa Anna owns immense herds of cattle, some forty or fifty thousand head, which graze upon it." ${ }^{21}$

Melville's proposal, to extrapolate an "ungulate irruptions model" from the Valle del Mezquital to all of New Spain, seems inappropriate in this light: "As predicted by the model of ungulate irruptions, wherever grazing animals were introduced in New Spain their population history mirrored the experience for the Valle del Mezquital; that is, they increased exponentially, peaked, crashed, and finally stabilized ... contemporaries correlated the decline in the animal populations with environmental deterioration and overexploitation." The Veracruz lowlands clearly did not undergo the sequence of environmental degradation predicted by the ungulate irruptions model. Lowland livestock increased exponentially during the sixteenth century, but they did not overshoot the range carrying capacity, did not devastate the environment, and did not suffer a population crash. Instead, the high densities of the sixteenth century persisted into the nineteenth. ${ }^{22}$

\section{The Pastoral Landscape}

Beyond allowing for an evaluation of the range of estimates of livestock densities during the colonial period, cartographic representation of the archival data manifests Naipaul's "historical bird's eye view" and begins to address land as landscape, 
as a spatial as well as temporal patterning of ecological elements and processes. The "ungulate irruptions model" neglects the spatial dimension of environment. Ecologists, once enamored of such successional models, have more recently recognized their ahistorical and aspatial nature, turning instead to landscape ecology. That theoretical perspective, pioneered by such geographers as Carl O. Sauer and Carl Troll, analyzes the reciprocal relationship between the nonrecurrent (historical) processes of landscape change and the environmental heterogeneity (spatial patterning) of landscapes. In that perspective, understanding such spatial processes as transhumance at scales ranging from local to regional becomes a central endeavor that transcends deductive successional models and the simplistic attribution of environmental degradation to an imbalance between livestock density and carrying capacity. High regional densities do not necessarily equate with overgrazing because seasonal variations in the distribution of forage allow pastoralists to take advantage of different landscape patches in different seasons. ${ }^{23}$

While the processes involved in the success of lowland livestock remain unclear, such a landscape perspective on ecological history does suggest an intriguing possibility, testable with further archival and field research: the Spaniards might have been able to maintain high livestock densities through a transhumant pastoralism based on semiferal, criollo cattle. Unlike the annual movements of sheep between highlands and lowlands, cattle transhumance was local. Although the data remains thin, the transhumant system introduced from Spain circa 1521 might have mitigated overgrazing by seasonally moving stock between wet and dry savanna, a strategy which reflected the ecological complimentary of environmental patches exploited by native cultures long before the coming of the Spaniards. A German naturalist and local land owner of the nineteenth century, Carl Sartorius, has left a description of the region's nineteenth-century pastoral ecology that probably reflects persistent antecedents. During the summer wet season, cattle would graze the dry savanna of the piedmont, but with "the cessation of the rains, the prairies fade, the soil dries up, the trees lose their foliage, the herds seek the forests and chasms." As the dry season progressed and floodwaters receded from the wetlands of the coastal plain, ranchers would burn the dry savanna and drive their semiferal cattle downslope to graze the wet savanna, reversing the process in spring as the floods once again inundated the wetlands. Understanding that local transhumance and its implications for the environment will require a more concerted archival reconstruction of patterns of land tenure and land use, particularly the relative movements of cattle and sheep throughout the year. Likewise, a better understanding of the extent and impact of burning, beyond the largely proscriptive ordinances, will require further field research. ${ }^{24}$

Whatever the processes involved in the success of colonial cattle, the herds did preempt the demographic recovery of the native population, without doubt the greatest tragedy of the Columbian Exchange. When Cortés landed at Veracruz, some half a million people lived in these lowlands. By 1600 , epidemic disease and exploitation had reduced the native population by 90 percent; forced relocation had simplified the settlement pattern to a shadow on the landscape. The Spaniards and their African slaves occupied the coast and a string of inns connecting 
the port to Mexico City, controlling the region as a resource hinterland and transportation corridor. By the middle of the seventeenth century, a few families had come to control the vast herds that ranged between coastal plain and piedmont. Two centuries later, General Santa Ana emerged from the ferment of the war for independence to dominate this lowland landscape as thoroughly as he did the Mexican political scene. With the agrarian revolution and land reform, migrants from the highlands took up ejido lands expropriated from the haciendas, and public irrigation and drainage projects made sugarcane economically competitive with cattle. By the time farmers began to repossess some of the pastures in the twentieth century, drainage of wetlands, irrigation of dry lands, and market integration, rather than ecological complementarity between the wet and the dry, dominated the development discourse.

Andrew Sluyter is Assistant Professor of Geography at the Pennsylvania State University. He received his Ph.D. from the University of Texas at Austin in 1995 for research on the cultural-ecological history and prehistory of Latin America and has published on that theme in Annals of the Association American Geographers, Geographical Review, Global and Planetary Change, and Latin American Antiquity. His recent research on long-term changes in forest landscapes of the Allegheny Plateau has begun to complement the earlier focus on tropical range lands.

\section{Notes}

My thanks to two anonymous reviewers and to Peirce Lewis and Adam Rome for kindly providing feedback on ideas and writing, all of which helped improve this article.

1. In an increasingly voluminous literature on the Columbian Exchange, a few key works do stand out: Carl O. Sauer, The Early Spanish Main (Berkeley: University of California Press, 1966); Alfred W. Crosby, The Columbian Exchange: Biological and Cultural Consequences of 1492 (Westport, Conn.: Greenwood Press, 1972); William Cronon, Changes in the Land: Indians, Colonists, and the Ecology of New England (New York: Hill and Wang, 1983); Carolyn Merchant, Ecological Revolutions: Nature, Gender, and Science in New England (Chapel Hill: University of North Carolina Press, 1989); Susanna Hecht and Alexander Cockburn, The Fate of the Forest: Developers, Destroyers and Defenders of the Amazon (New York: Harper Collins, 1990).

2. The plague-of-livestock thesis has a long history and qualifies as the standard paradigm in the scholarly, policy, and popular literature. See Lesley Byrd Simpson, Exploitation of Land in Central Mexico in the Sixteenth Century (Berkeley: University of California Press, 1952), and Many Mexicos (Berkeley: University of California Press, 1960), 17; Crosby, Columbian Exchange, 86-95, 111-13; Erik P. Eckholm, Losing Ground: Environmental Stress and World Food Prospects (New York: W. W. Norton, 1976), 34; Elinor G. K. Melville, "The Pastoral Economy and Environmental Degradation in Highland Central Mexico, 1530-1600" (Ph.D. diss., University of Michigan, 1983), and "Environmental and Social Change in the Valle del Mezquital, Mexico, 1521-1600," Compara- 
tive Studies in Society and History 32 (1990): 24-53, and A Plague of Sheep: Environmental Consequences of the Conquest of Mexico (Cambridge: Cambridge University Press, 1994).

For examples of the counterargument, see Karl W. Butzer, "The Americas Before and After 1492: An Introduction to Current Geographical Research," Annals of the Association of American Geographers 82 (1992): 345-68, and Karl W. Butzer, "Judgment of Understanding?: Reflections on 1492," Queen's Quarterly 99 (1992): 581-600; B. L. Turner II and Karl W. Butzer, "The Columbian Encounter and Land-Use Change," Environment 34 (1992): 16-20, 37-44; Karl W. Butzer and Elisabeth K. Butzer, "The Sixteenth-Century Environment of the Central Mexican Bajío: Archival Reconstruction from Colonial Land Grants and the Question of Spanish Ecological Impact," in Culture, Form, and Place: Essays in Cultural and Historical Geography, ed. Kent Mathewson (Baton Rouge: Geoscience Publications, Department of Geography and Anthropology, Louisiana State University, 1993), 89-124, and "Transfer of the Mediterranean Livestock Economy to New Spain: Adaptation and Ecological Consequences," in Global Land Use Change: A Perspective from the Columbian Encounter, ed. B. L. Turner II et al. (Madrid: Consejo Superior de Investigaciones Científicas, 1995), 15193.

3. For overviews of the archival databases, see Simpson, Exploitation; François Chevalier, La Formation des Grands Domaines au Mexique: Terre et Société aux XVI-XVII Siècles (Paris: Institut d'Ethnologie, 1952); Hanns J. Prem, Milpa y Hacienda: Tenencia de la Tierra Indígena y Española en la Cuenca del Alto Atoyac, Puebla, México (15201650), trans. of Milpa und Hacienda: Indianischer und Spanischer Landbesitz im Becken des Alto Atoyac, Puebla, México (1520-1650), trans. María Martínez Peñaloza (Mexico: Centro de Investigaciones y Estudios Superiores en Antropología Social, Estado de Puebla, and Fondo de Cultura Económica, 1988); Andrew Sluyter, "Landscape Change and Livestock in Sixteenth-Century New Spain: The Archival Data Base," Conference of Latin Americanist Geographers Yearbook 23 (1997): 27-39. The bulk of the land grants are in two sections of the Archivo General de la Nación [hereafter AGN], mainly in AGN-Mercedes, but also in AGN-Tierras. The two errant volumes of grants are ms. 140, Kraus Collection, Library of Congress, Washington, D.C., and ms. 1121, Ayer Collection, Newberry Library, Chicago, Ill.

4. On Spanish transhumance in Iberia and its diffusion to New Spain, see William E. Doolittle, "La Marismas to Pánuco to Texas: The Transfer of Open Range Cattle Ranching from Iberia through Northeastern Mexico," Conference of Latin Americanist Geographers Yearbook 13 (1987): 3-11; Karl W. Butzer, "Cattle and Sheep from Old to New Spain: Historical Antecedents," Annals of the Association of American Geographers 78 (1988): 29-56; Terry G. Jordan, North American Cattle-Ranching Frontiers: Origins, Diffusion, and Differentiation (Albuquerque: University of New Mexico Press, 1993); Butzer and Butzer, "Transfer"; Andrew Sluyter, "The Ecological Origins and - Consequences of Cattle Ranching in Sixteenth-Century New Spain," The Geographical Review 86 (1996): 161-77. The quote is from Simpson, Exploitation, 21. The stocking rates typically, but not invariably, specified in mercedes from the 1560 onward clearly refer to minimum stocking rates, with no upper limits prescribed: "That within one year the said estancia be stocked with two thousand head of the said small stock and ... a at no time may be abandoned nor with fewer number of stock on pain of this grant becoming null and void," AGN-Mercedes, vol. 10, f. 61 (1575); "That within one year the said ranch has been stocked with the said large stock which will be at least five hundred head," AGN-Mercedes, vol. 10, f. 182 (1576); “That within the next year each 
one of the said ranches has been stocked with two thousand head of the said small livestock," AGN-Mercedes, vol. 33, f. 113 (1617).

5. The two seminal studies are Simpson, Exploitation, and Chevalier, La Formation. Some key subsequent studies are Prem, Milpa y Hacienda; Jack A. Licate, Creation of a Mexican Landscape: Territorial Organization and Settlement in the Eastern Puebla Basin, 1520-1605 (Chicago: Department of Geography, University of Chicago, 1981); Melville, Plague of Sheep, and "Environmental and Social Change," and "The Pastoral Economy," and "The Long-Term Effects of the Introduction of Sheep into Semi-Arid Sub-Tropical Regions," in Changing Tropical Forests: Historical Perspectives on Today's Challenges in Central and South America, ed. Harold K. Steen and Richard P. Tucker (Durham, N.C.: Forest History Society, 1992), 144-53, and "Land-Labour Relations in Sixteenth-Century Mexico: The Formation of Grazing Haciendas," Slavery and Abolition 15 (August 1994): 26-35; M. Irais Piñón Flores, "La Tenencia de la Tierra en la Región de Tlazazalca-Zacapu-Huaniqueo," in Carlos S. Paredes M. et al., Michoacan en el Siglo XVI (Morelia: Fimax, 1984), 105-89; Rolf S. Widmer, Conquista y Despertar de las Costas de la Mar del Sur (1521-1684) (Mexico: Consejo Nacional para la Cultura y las Artes, 1990); Butzer and Butzer, "Sixteenth-Century Environment." The main elements of the Butzers' critique appear in Karl W. Butzer, "Ethno-Agriculture and Cultural Ecology in Mexico: Historical Vistas and Modern Implications," Conference of Latin Americanist Geographers Yearbook, Benchmark 1990 17/18 (1992): 144, 148; Butzer and Butzer, "Sixteenth-Century Environment," 103-104, 121. But also see Karl W. Butzer, "No Eden in the New World," Nature 362 (4 March 1993): 15-17; and Butzer and Butzer, "Transfer," 179. Details of the cartographic method applied to the first two methodological issues appear in Sluyter, "Landscape Change and Livestock."

6. Frederick A. Ober, Travels in Mexico and Life Among the Mexicans (Boston: Estes and Lauriat, 1887), 189. For the prominence of the study region in the livestock economy of New Spain, see Simpson, Exploitation; Chevalier, Land and Society; Butzer and Butzer, "Transfer"; Peter Gerhard, A Guide to the Historical Geography of New Spain (Norman: University of Oklahoma Press, 1993), 363-67. For regional studies pertaining to the ecological consequences of the colonial period in the study region, see citations in Sluyter, "Landscape Change and Livestock"; Alfred H. Siemens et al., "Evidence for a Cultivar and a Chronology from Patterned Wetlands in Central Veracruz, Mexico," Science 242 (7 October 1988): 105-7; Alfred H. Siemens, "A Favored Place: An Interpretation of the Development of a Wetland Landscape in Central Veracruz, Mexico," in Person, Place, Thing: Interpretive and Empirical Essays in Cultural Geography, ed. Shue Tuck Wong (Baton Rouge: Geoscience Publications, Department of Geography and Anthropology, Louisiana State University, 1992), 195-210, and "Land-Use Succession in the Gulf Lowlands of Mexico," in Global Land Use Change: A Perspective from the Columbian Encounter, ed. B. L. Turner II et al. (Madrid: Consejo Superior de Investigaciones Científicas, 1995), 195-220; Sluyter, "Ecological Origins," and "Regional, Holocene Records of the Human Dimension of Global Change: Sea-Level and Land-Use Change in Prehistoric Mexico," Global and Planetary Change 14 (1997): $127-46$.

7. See Andrew Sluyter, "Changes in the Landscape: Natives, Spaniards, and the Ecological Restructuration of Central Veracruz, Mexico During the Sixteenth Century" (Ph.D. diss., University of Texas at Austin, 1995), 507-620. Continued archival research since completion of that dissertation has recovered additional mercedes, totaling one cattle estancia and twenty-three sheep estancias: AGN-Mercedes, vol. 15, ff. 182v-183v; vol. 16, f. $27 \mathrm{v}$; vol. 17, ff. 25v-26v; vol. 18. ff. 373v-374; vol. 19, ff. 130-131, 133v-134v; vol. 20 , 
ff. 112v-114v, 117-120v, 141-142, 182-182v; vol. 29, ff. 139-139v. A new "Guía al Mercedes" made some of that additional recovery possible; also, several volumes which had long been under restoration or in the photoduplication department eventually became available.

8. Simpson, Exploitation, assumes that years with zero-to-few grants in AGN-Mercedes represent lost volumes and therefore interpolates between "years of fullest coverage" and "corrects" by adding 40.5 percent to documented "Spanish cattle grants" and 25 percent to "Spanish sheep grants." Melville, Plague of Sheep, infers 455 of her claimed total of 862 sheep estancias for the Valle del Mezquital on the basis of mention as neighboring estancias in existing mercedes. A major hazard of that method lies in assuming that an estancia mentioned in a merced as belonging to Hernando Hernández represents a "lost" grant simply because no grant in that name remains. Many grants changed owners soon after they were awarded (legally or illegally), and mentions of such estancias in subsequent mercedes name the current owner rather than the original grantee. The names of estancias themselves, often quite generic, also changed and provide but tentative identifications. Thus, Melville may have inferred many more grants than ever existed and grossly overestimated the number of estancias. Melville, Plague of Sheep, 125-27, does try to minimize the hazards of duplication by comparing landscape referents and by applying a downward adjustment for one period to "take into account the possibility of confusion with earlier holdings," but the often equivocal nature of such referents, the large proportion of inferred estancias in the Valle del Mezquital compared to the Veracruz lowlands ( 455 out of 862 in a region of 10,029 square kilometers versus 4 out of 232 in a region of 5,250 square kilometers), and the lack of evidence for nondocumented, "squatter" estancias in Veracruz all suggest the need for mapping the Valle de Mezquital grants in space and time in order to preclude counting the same location several times simply because ownership changed.

9. Simpson, Exploitation, 21, employs a factor of three to "correct" for the putative difference between the de jure and de facto extent of various areas. On sixteenth-century cattle transhumance in the Veracruz lowlands, see Sluyter, "Ecological Origins."

10. On this method, see Simpson, Exploitation; Butzer and Butzer, "Sixteenth-Century Environment," and "Transfer." The de jure minimum densities of 0.29 head per hectare for cattle and 2.6 head per hectare for sheep derive from 500 cows per 1,747 hectares and 2,000 sheep per 776 hectares.

11. Multiple examples indicate high rates for particular estancias. See Simpson, Exploitation, 13; Richard J. Morrisey, "Colonial Agriculture in New Spain," Agricultural History 31 (1957): 24-29. Melville calculates livestock densities ("grazing rates") for each subregion of the Valle del Mezquital by abstracting scattered references to livestock numbers grazing particular areas or estancias ("stocking rates") throughout that region, multiplying by the total number of estancias ("documented" plus "undocumented squatters") for each subregion for each decade, and dividing by the area of each subregion to allow for grazing on commonage beyond the estancias themselves. The highest calculated density is 7.85 sheep per hectare for the Tula subregion during the 1570 ; the highest calculated density for the Valle del Mezquital as a whole is 4.36 sheep per hectare during the 1580 s, falling in the "high" category of Melville's "graduated scale of grazing intensity." Plague of Sheep, 49-51, 78-84. The 1580 relación geográfica, a standardized geographical report, is in the Joaquin García Icazbalceta Collection of the University of Texas at Austin, ms. XXV-8, f. 5 . The viceroy did not grant any estancias in the Veracruz lowlands in 1580 , so the report must relate to the situation in the late 157 os. 
12. Simpson, Exploitation, 21. Butzer and Butzer make similar comparisons, but conclude that the "seemingly impossible densities of livestock" in New Spain must relate to transhumance between seasonally complimentary pastures. "Transfer," 156. For a critique of "biologized" range management which ignores cultural context, see Matthew Turner, "Overstocking the Range: A Critical Analysis of the Environmental Science of Sahelian Pastoralism," Economic Geography 69 (1993): 402-21; Peder N. de Leeuw and John C. Tothill, "The Concept of Rangeland Carrying Capacity in Sub-Saharan Africa: Myth or Reality," in Range Ecology at Disequilibrium: New Models of Natural Variability and Pastoral Adaptation in African Savannas, ed. Roy H. Behnke Jr., Ian Scoones, and Carol Kerven (London: Overseas Development Institute, 1993), 77-88. On livestock densities, see P. J. Edwards and N. M. Tainton, "Managed Grasslands in South Africa," in Ecosystems of the World ${ }_{17}$ A, Managed Grasslands, Regional Studies, ed. A. I. Breymeyer (Amsterdam: Elsevier, 1990), 99-128; Ruth M. Gatenby, Sheep (London: MacMillan, 1991), 12; P. V. Rattray, "Sheep Production from Managed Grasslands," in Ecosystems of the World ${ }_{17} B$, Managed Grasslands, Analytical Studies, ed. R. W. Snaydon (Amsterdam: Elsevier, 1987), 113-22; W. Holmes, "Beef Production from Marginal Grasslands," in Ecosystems of the World 17B, 91-100; David H. White, "Stocking Rate," in Ecosystems of the World ${ }_{17} B$, 227-38; Carta Uso del Suelo y Vegetación, 1:250,000 thematic map (Mexico: Instituto Nacional de Estadística, Geografía e Informática, 1984), sheets E14-3, E14-6, E15-1-4.

13. Estadística Ganadera de la República (Mexico: Dirección General de Estadística Secretaría de Fomento, Colonización, e Industria, 1903). For background on the livestock economy, see David Skerritt Gardner, Una Historia Agraria en el Centro de Veracruz, 1850-1940 (Jalapa, Veracruz: Universidad Veracruzana, Centro de Investigaciones Históricas, 1989), 29-33; Richard J. Salvucci, Textiles and Capitalism in Mexico: An Economic History of the Obrajes, 1539-1840 (Princeton: Princeton University Press, 1987), 135-67; Luis Chávez Orozco and Enrique Florescano, Agricultura e Industria Textil de Veracruz, Siglo XIX (Jalapa, Veracruz: Universidad Veracruzana, 1965), 194; James J. Parsons, “The 'Africanization' of the New World Tropical Grasslands," Tubinger Geographische Studien 34 (1970): 141-53 (principally Guinea and Pará grass); Estadísticas Históricas de México (Mexico: Instituto Nacional de Estadística, Geografía e Informática, 1990), 21, 48-51; La Ganadería en el Estado de Veracruz (Jalapa, Veracruz: Instituto de Ciencias de Universidad Veracruzana, 1965), 13.

14. The Mexican municipio, or municipality, roughly equates to the county of the United States. Estadística Ganadera; Estadísticas Históricas, xii, 423-25. The categories "large livestock" and "small livestock" parallel the Spanish categories "ganado mayor" and "ganado menor." On herd ecology, see Holmes, "Beef"; Rattray, "Sheep”; L. L. Wilson and J. C. Burns, "Utilization of Forages with Beef Cows," in Forages: The Science of Grassland Agriculture, ed. Maurice E. Heath, Darrel S. Metcalfe, and Robert F. Barnes (Ames: Iowa State University Press, 1973), 677-89. On forage consumption, see John Chesworth, Ruminant Nutrition (London: MacMillan, 1992), 138; Predicting Feed Intake of Food-Producing Animals (Washington: National Academy Press, 1987), 75. On Merinos and criollo livestock, see Chevalier, Land and Society, 106-7; E. Terril, Ivan L. Lindahl, and Donald A. Price, "Sheep: Efficient Users of Forage," in Forages, 70314; L. L. Wilson and J. C. Burns, "Utilization of Forages," 677-89; Gatenby, Sheep, 37, 41; Jordan, North American Cattle-Ranching Frontiers, 67; J. E. Rouse, The Criollo: Spanish Cattle in the Americas (Norman: University of Oklahoma Press, 1977), 253-54. 
15. Estadística Ganadera; Los Municipios de Veracruz (Mexico: Secrataría de Gobernación and Gobierno del Estado de Veracruz-Llave, 1988). See Melville, Plague of Sheep, 84, on the rationale for including the entire area of a region rather than attempting to determine the area of pasture lands. The included municipalities enumerated 30,481 cattle, 3,090 horses, 596 mules, 138 sheep, and 189 goats, as well as 1,405 donkeys and 1,217 pigs.

16. An estancia falling more than half within a municipality counts as one, an estancia falling half within a municipality counts as half, and an estancia falling more than half outside of a municipality counts as zero.

17. My concerns with Melville's conclusions remain methodological and theoretical rather than empirical. Despite serious methodological lapses, her conclusions may well withstand empirical scrutiny for the Valle del Mezquital itself. However, see Butzer and Butzer, "Transfer," 179; Sarah L. O'Hara, review of A Plague of Sheep: Environmental Consequences of the Conquest of Mexico, by Elinor G. K. Melville, Mountain Research and Development 15 (1995): 359-61.

18. Sluyter, "Regional, Holocene Records," 140-42.

19. On prehispanic environmental degradation, see E. S. Deevey Jr. et al., "Maya Urbanism: Impact on a Tropical Karst Environment," Science 206 (19 October 1979): 298306; Sarah L. O'Hara, F. Alayne Street-Perrott, and Timothy P. Burt, "Accelerated Soil Erosion Around a Mexican Highland Lake Caused by Prehispanic Agriculture," Nature 362 (4 March 1993): 48-51.

20. Sluyter, "Changes in the Landscape," 292-94.

21. Transcription from "La Relación de Corral," Archivo General de Indias, México, legajo 1864, in Alfred H. Siemens and Lutz Brinckmann, "El Sur de Veracruz a Finales del Siglo XVIII, un Análisis de la 'Relación' de Corral," Historia Mexicana 26 (1976): 311; Carl Sartorius, Mexico About 1850 (Stuttgart: F. A. Brockhaus, 1961), 9-10; Waddy Thompson, Recollections of Mexico (New York: Wiley and Putnam, 1846), 12-13. Also see Chávez Orozco and Florescano, Agricultura e Industria, 54, 194.

22. Melville, Plague of Sheep, 47-55, 162-63. Perhaps a more detailed, municipality-bymunicipality environmental history of the Veracruz lowlands will eventually reveal a more complex process in which sheep-dominated zones suffered degradation of the range, as suggested by the great differences between livestock densities in 1619 and 1902 for Cuitlahuac and Carrillo Puerto, the two municipalities which were the near exclusive domain of sheep in 1619. Even so, those two municipalities represent less than 8 percent of the study region's area.

23. V. S. Naipaul, $A$ Way in the World (New York: Vintage International, 1995), 11. For seminal and current work in landscape ecology, see Carl O. Sauer, "The Morphology of Landscape," in Land and Life, ed. John Leighly (Berkeley: University of California Press, 1969), 315-50; Carl Troll, "Landscape Ecology (Geoecology) and Biogeocenology: A Terminological Study," Geoforum 8 (1971): 43-46; S. T. A. Pickett and M. L. Cadenasso, "Landscape Ecology: Spatial Heterogeneity in Ecological Systems," Science 269 (21 July 1995): 331-34; and citations in R. T. T. Forman and M. Gordon, Landscape Ecology (New York: Wiley, 1986).

24. On the introduction of Iberian cattle transhumance into the Veracruz region, see Sluyter, "Ecological Origins." On prehispanic land use, see Siemens, "A Favored Place," and "Land-Use Succession in the Gulf Lowlands"; Andrew Sluyter and Alfred H. Siemens, "Vestiges of Prehispanic, Sloping-Field Terraces on the Piedmont of Central Veracruz, Mexico," Latin American Antiquity 3 (1992): 148-6o; Sartorius, Mexico About 1850, 410. 